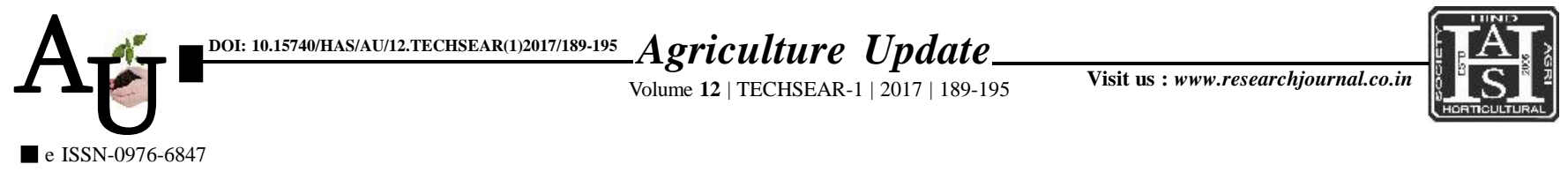

\title{
Research Article: Seasonal incidence and influence of dates of sowing on thrips infestation in Kharifonion
}

\section{B.V. SUMALATHA, D.R. KADAM, N.E. JAYEWAR AND Y.C. THAKARE}

Article Chronicle : Received :

11.07.2017;

Accepted :

26.07.2017

Author for correspondence :

\section{B.V. SUMALATHA}

Department of

Agricultural

Entomology, Vasantrao

Naik Marathwada Krishi

Vidyapeeth, PARBHANI

(M.S.) INDIA

Email:sumachaaru1@

gmail.com

See end of the article for

authors' affiliations
SUMMARY : A field experiment was conducted at Research Farm of Department of Agricultural Entomology, VNMKV, Parbhani, during Kharif 2016, to study The seasonal incidence of onion thrips and effect of transplanting dates on thrips infestation in Kharif onion, their effect on ladybird beetle and onion bulb yield. The maximum incidence of thrips was noticed during October to December 2016. Non significant correlation was observed between weather parameters and thrips population in onion. Whereas the predator delivered a positive tropic interaction and maximum count was obtained during November when pest abundance was high. The correlation of coccinellids with temperature, wind velocity and evaporation was significantly negative. Studies on effect of transplanting dates on thrips revealed that the lower population of thrips was noticed in the crop transplanted on $20^{\text {th }}$ July and $30^{\text {th }}$ July during seedlings stage. The higher population of thrips was recorded in seedling transplanted on $10^{\text {th }}$ September, $30^{\text {th }}$ August and $20^{\text {th }}$ August.

How to cite this article : Sumalatha, B.V., Kadam, D.R., Jayewar, N.E. and Thakare, Y.C. (2017). Seasonal incidence and influence of dates of sowing on thrips infestation in Kharif onion. Agric. Update, 12(TECHSEAR1) : 189-195; DOI: 10.15740/HAS/AU/12.TECHSEAR(1)2017/189-195. 